\title{
Xanthophylls Modulate Palmitoylation of Mammalian $\beta$-Carotene Oxygenase 2
}

\author{
Sheetal Uppal $\left.{ }^{1}{ }^{(}\right)$, Sergey A. Dergunov ${ }^{2}\left(\mathbb{D}\right.$, Weiyu Zhang ${ }^{2}$, Susan Gentleman ${ }^{1}$, T. Michael Redmond ${ }^{1, *(\mathbb{D})}$ \\ Eugene Pinkhassik ${ }^{2, *}$ and Eugenia Poliakov ${ }^{1, *}$ \\ 1 Laboratory of Retinal Cell \& Molecular Biology, National Eye Institute, National Institutes of Health, \\ Bethesda, MD 20892, USA; sheetal.uppal2@nih.gov (S.U.); sbgman@verizon.net (S.G.) \\ 2 Department of Chemistry, University of Connecticut, Storrs, CT 06269, USA; \\ sergey.dergunov@uconn.edu (S.A.D.); weiyu.zhang@uconn.edu (W.Z.) \\ * Correspondence: redmondd@nei.nih.gov (T.M.R.); eugene.pinkhassik@uconn.edu (E.P.); \\ poliakove@nei.nih.gov (E.P.)
}

Citation: Uppal, S.; Dergunov, S.A.; Zhang, W.; Gentleman, S.; Redmond, T.M.; Pinkhassik, E.; Poliakov, E. Xanthophylls Modulate Palmitoylation of Mammalian $\beta$-Carotene Oxygenase 2. Antioxidants 2021, 10, 413. https://doi.org/10.3390/antiox 10030413

Academic Editor: Torsten Bohn

Received: 30 January 2021

Accepted: 2 March 2021

Published: 9 March 2021

Publisher's Note: MDPI stays neutral with regard to jurisdictional claims in published maps and institutional affiliations.

Copyright: (c) 2021 by the authors. Licensee MDPI, Basel, Switzerland. This article is an open access article distributed under the terms and conditions of the Creative Commons Attribution (CC BY) license (https:// creativecommons.org/licenses/by/ $4.0 /)$.

\begin{abstract}
An extensive body of work has documented the antioxidant role of xanthophylls (lutein and zeaxanthin) in human health and specifically how they provide photoprotection in human vision. More recently, evidence is emerging for the transcriptional regulation of antioxidant response by lutein/lutein cleavage products, similar to the role of $\beta$-carotene cleavage products in the modulation of retinoic acid receptors. Supplementation with xanthophylls also provides additional benefits for the prevention of age-related macular degeneration (AMD) and attenuation of Alzheimer's disease symptoms. Mammalian $\beta$-carotene oxygenase 2 (BCO2) asymmetrically cleaves xanthophylls as well as $\beta$-carotene in vitro. We recently demonstrated that mouse $\mathrm{BCO} 2(\mathrm{mBCO} 2)$ is a functionally palmitoylated enzyme and that it loses palmitoylation when cells are treated with $\beta$-carotene. The mouse enzyme is the easiest model to study mammalian BCO2 because it has only one isoform, unlike human $\mathrm{BCO} 2$ with several major isoforms with various properties. Here, we used the same acyl-RAC methodology and confocal microscopy to elucidate palmitoylation and localization status of $\mathrm{mBCO} 2$ in the presence of xanthophylls. We created large unilamellar vesicle-based nanocarriers for the successful delivery of xanthophylls into cells. We demonstrate here that, upon treatment with low micromolar concentration of lutein $(0.15 \mu \mathrm{M}), \mathrm{mBCO} 2$ is depalmitoylated and shows partial nuclear localization $(38.00 \pm 0.04 \%)$, while treatment with zeaxanthin $(0.45 \mu \mathrm{M})$ and violaxanthin $(0.6 \mu \mathrm{M})$ induces depalmitoylation and protein translocation from mitochondria to a lesser degree ( $20.00 \pm 0.01 \%$ and $35.00 \pm 0.02 \%$, respectively). Such a difference in the behavior of $\mathrm{mBCO} 2$ toward various xanthophylls and its translocation into the nucleus in the presence of various xanthophylls suggests a possible mechanism for transport of lutein/lutein cleavage products to the nucleus to affect transcriptional regulation.
\end{abstract}

Keywords: BCO2; palmitoylation; xanthophylls; large unilamellar vesicles; $\beta$-carotene

\section{Introduction}

Most consideration of the antioxidant function of xanthophylls, polar hydroxy carotenoids, has focused on their chemical role in quenching excited triplet states of singlet oxygen by virtue of their extended conjugated bond systems. However, there is emerging evidence for a role of xanthophyll/xanthophyll cleavage products in modulating transcriptional regulation of antioxidant gene pathways.

In respect of their best-known role, high dietary intake of xanthophylls may offer protection against age-related macular degeneration (AMD), cancer and neurodegenerative diseases [1,2]. While xanthophylls account for less than $20 \%$ of the total carotenoids in the human diet, in the blood plasma the amount of xanthophylls increases to about $40 \%$ and is increased even more in the brain and retina $[3,4]$. Thus, xanthophylls account for about $70 \%$ of total carotenoids in all brain regions. Xanthophylls are selectively concentrated in the 
most vulnerable regions of polyunsaturated lipid-enriched membranes, such as in the retinal photoreceptor outer segments [5]. This localization is ideal for macular xanthophylls to act as lipid-soluble antioxidants, which is the most likely mechanism of protection against photooxidation [6]. Additionally, the high membrane solubility and preferential transmembrane orientation of macular xanthophylls [6,7] enhance their chemical and physical stability in retina and brain membranes [8] and maximize their protective action against oxidative stress in these organs [9]. Xanthophylls are capable of quenching excited triplet states of potent singlet oxygen photosensitizers. Free all-trans-retinal may absorb light and transfer energy from its excited triplet state to molecular oxygen, generating singlet oxygen [10]. It is postulated that the close proximity of xanthophylls allows effective energy transfer from excited all-trans-retinal to xanthophyll and prevents singlet oxygen generation by this photosensitizer [11]. By this mechanism, the largest part of excess energy can be transferred from potentially harmful triplets of photosensitizers to xanthophylls and dissipated as heat. The ratio of zeaxanthin (and meso-zeaxanthin) to lutein is higher in the macula where the strongest light is received compared to peripheral low-light-vision regions of the eye [3]. A portion of dietary lutein is converted to meso-zeaxanthin, a stereoisomer of zeaxanthin, presumably in retinal pigment epithelium (RPE) by RPE65 isomerase [12]. This preference for zeaxanthin has been suggested to be due to a greater antioxidant capacity, possibly due to the longer system of conjugated double bonds and membrane-stabilizing function of zeaxanthin (and meso-zeaxanthin) compared to lutein [12,13]. Xanthophylls are delivered to the retina with the help of high-density lipoprotein (HDL) [14] and xanthophyll-binding proteins [15]. Xanthophyll-binding proteins have been described for both zeaxanthin and lutein [16]. However, the role of $\beta$-carotene oxygenase 2 (BCO2), an enzyme that can cleave xanthophylls [17], is not thoroughly studied.

$\mathrm{BCO} 2$ is present in the brain, retina and RPE; everywhere xanthophylls accumulate. $\mathrm{BCO} 2$ is well characterized as a carotenoid metabolizing enzyme [18-21] that is widely distributed in tissues, including the retina, RPE, skeletal muscle, small intestine and liver [22]. A deficiency of $\mathrm{BCO} 2$ was found to be associated with accumulation of carotenoids in the adipose tissues [23], such as subcutaneous adipose tissue. This leads to the occurrence of yellow fat in sheep [24], cow [25], and yellow skin in chicken [26]. The abSNP rs2250417 in $\mathrm{BCO} 2$ has one of the strongest instances of statistical significance for association with AMD of carotenoid metabolism genes [27]. The two minor alleles for SNP rs2250417 in BCO2 account for an increase in risk for AMD by almost 50\% [27]. Additionally, BCO2 deficiency in mice leads to stimulation of oxidative stress and inflammation in hypothalamic tissues on a low carotenoid diet [28].

To better study the role of BCO2 in metabolism of xanthophylls, we developed xanthophyll-containing large unilamellar vesicles (LUVs) to efficiently deliver xanthophylls to cells. We chose to express mBCO2 in human cell culture because it has only one major isoform while human and monkey BCO2 have several major isoforms. Only one of these has a N-terminal mitochondrial signal and it is still hotly debated if this isoform manifests as an active BCO2 enzyme [17,29-31]. Here, using LUVs, we describe that lutein modulates the palmitoylation status of mouse $\mathrm{BCO} 2(\mathrm{mBCO} 2)$ and changes its cellular localization in HEK293F cells from mitochondria to nucleus upon binding. We have detected the same effect for zeaxanthin and violaxanthin but to a lesser degree and our modeling analysis suggests a possible explanation of the difference. Accumulation in the nucleus of mBCO2 loaded with xanthophylls could directly affect gene expression and may provide a mechanism whereby xanthophylls/xanthophyll cleavage products could elicit a transcriptional response to oxidant stress.

\section{Materials and Methods}

\subsection{Materials}

1,2-dimyristoyl-sn-glycero-3-phosphocholine (DMPC), 1,2-dimyristoyl-sn-glycero3-phospho-L-serine (sodium salt) (DMPS), 1,2-dipalmitoyl-sn-glycero-3-phosphocholine (DPPC), 1,2-dipalmitoyl-sn-glycero-3-phospho-L-serine (sodium salt) (DPPS) were pur- 
chased from Avanti Polar Lipids, Inc. (Alabaster, AL, USA). (R)-(+)-limonene and tricine were used as received (Sigma-Aldrich, St. Louis, MO, USA). Nitrogen-purged hexane, dichloromethane $(\mathrm{DCM})$ and chloroform $\left(\mathrm{CHCl}_{3}\right)$ were passed through an activated alumina column, dried with $\mathrm{CaSO}_{4}$, and stored over $4 \AA$ molecular sieves. All kinetic experiments were performed with the same batch of samples. Lutein and violaxanthin were purchased from Cayman Chemicals (Ann Arbor, MI, USA), and zeaxanthin (65\%) from Toronto Research Chemicals (Toronto, ON, Canada).

\subsection{Preparation of Large Unilamellar Vesicles (LUVs) with Xanthophylls}

Aqueous lipid dispersions of LUVs were prepared by first mixing the required amounts of lipids, carotenoids, and limonene (used here for better solubilization of carotenoids in the lipid bilayer) in chloroform. All samples were prepared using similar protocol to the one described previously [32]. Amounts of lipids were the same, $10 \mathrm{mg} / \mathrm{mL}$, limonene: lipid = 1:1 (mol/mol), while amounts of carotenoids were different: $0.5 \mathrm{mg}$ zeaxanthin in $1.5 \mathrm{~mL}$ of buffer (using DPPC/DPPS or DMPC/DMPS lipids); the lutein preparation contained $0.25 \mathrm{mg}$ lutein in $1.5 \mathrm{~mL}$ of buffer (using DMPC/DMPS lipids); and the violaxanthin preparation contained $0.25 \mathrm{mg}$ violaxanthin in $1.5 \mathrm{~mL}$ of buffer (using DMPC/DMPS lipids). All samples were prepared with a mole fraction of $7 \%$ PS (sn-glycero-3-phospho-L-serine) to avoid multilamellar stack formation [33]. The solvent was evaporated with an inert gas stream to constant weight. The lipid film was hydrated with $100 \mathrm{mM}$ tricine-KOH pH 8.0 buffer (prepared with $\mathrm{H}_{2} \mathrm{O}$ ) at room temperature with intermittent gentle vortex mixing. The lipid suspension was passed through $0.4,0.2,0.1 \mu \mathrm{m}$ Nucleopore polycarbonate membranes (21 times through each membrane) using a miniextruder (Avanti Polar Lipids). The LUVs were mixed with hexane and shaken gently for $20 \mathrm{~min}$ to remove limonene as confirmed by GC-MS. The LUVs were then decanted from the organic layer and the aqueous solution was purged with nitrogen and degassed to remove traces of hexane.

\subsection{Generation of Expression Vectors}

Mouse BCO2 cDNAs were prepared as described [34] and used to generate vectors for the expression of $\mathrm{BCO} 2$ in mammalian cells. Briefly, BCO2 was subcloned into the bicistronic expression vector pVitro2 (InvivoGen, San Diego, CA, USA) and into the Gateway cloning vector pcDNA6.2c-Lumio-DEST vector (Thermo Fisher (Invitrogen), Carlsbad, CA, USA) to generate untagged or C-terminal V5/lumio tagged versions of mouse BCO2, respectively. All constructs and mutants were sequenced to verify the orientation and accuracy of the ORFs and/or the changes introduced.

\subsection{Cell Culture}

Human 293F FreeStyle (Thermo Fisher, Invitrogen) suspension cells were grown in serum-free FreeStyle 293 expression medium (Invitrogen) and transfected according to the previously published protocol [35]. Briefly, a typical transfection experiment used $3 \times 10^{7}$ cells in $28 \mathrm{~mL}$ of FreeStyle medium mixed with $2 \mathrm{~mL}$ of OptiMem-I reduced serum medium containing $40 \mu \mathrm{L} 293$ fectin transfection reagent (Invitrogen) and $20 \mu \mathrm{g}$ of each expression plasmid under study. Cells were grown with shaking at $125 \mathrm{rpm}$ on an orbital shaker platform in a $37{ }^{\circ} \mathrm{C}$ incubator with a humidified atmosphere of $8 \% \mathrm{CO}_{2}$ for $48 \mathrm{~h}$ total. In total, $200 \mu \mathrm{L}$ of vesicles with xanthophylls were added, incubating for $5 \mathrm{hr}$ under standard growth conditions. 


\subsection{Antibodies}

Rabbit polyclonal antibody 186 was custom made against the mouse $\mathrm{BCO} 2$ multiple antigenic peptides (MAP)-SKFLQSDTYKANSAG peptide and 7055 rabbit polyclonal antibody was produced by co-immunization of the two human BCO2 MAP-SHENLHQEDL EKEGGIE and MAP-QDNGRTLEVYQLQNLRKAG peptides.

\subsection{Characterization of Large Unilamellar Vesicles (LUVs) with Xanthophylls \\ 2.6.1. Dynamic Light Scattering (DLS)}

The hydrodynamic diameter and polydispersity index (PDI) were measured at $30^{\circ} \mathrm{C}$ on a Malvern Nano-ZS zetasizer (Malvern Instruments Ltd., Worcestershire, UK) equipped with a $4 \mathrm{~mW}$ helium-neon laser operated at $633 \mathrm{~nm}$ with a fixed scattering angle of $173^{\circ}$. An $80 \mu \mathrm{L}$ sample was placed into disposable cuvettes without dilution $(70 \mu \mathrm{L}$, center height $8.5 \mathrm{~mm}, \mathrm{BRAND}^{\circledR}$ UV-Cuvette micro). Data were processed using non-negative least squares (NNLS) analysis.

\subsubsection{GC-MS Analysis}

A Shimadzu GC-2010 Plus system with an AOC-20i Auto-Injector and a GCMSQP2010 SE ion trap MS system (Shimadzu, Kyoto, Japan) was used for GC-MS analysis using the electron impact ionization mode. Chromatographic separations were performed on a Shimadzu SH-Rxi-5SiL MS capillary column $(30 \mathrm{~m} \times 0.25 \mathrm{~mm}, 0.25 \mathrm{~mm}$ film thickness; non-polar phase: Crossbond ${ }^{\mathrm{TM}} 100 \%$ dimethyl polysiloxane as stationary phase). The temperatures of the injector and the GC-MS transfer line were 170 and $280^{\circ} \mathrm{C}$, respectively. The carrier gas was ultrahigh purity helium (Airgas); the flow rate was $1.0 \mathrm{~mL} / \mathrm{min}$. The mass spectrometer was operated using the following parameters: the ratio of the split injection was 20:1, ionization voltage was $70 \mathrm{eV}$; ion source temperature was $200{ }^{\circ} \mathrm{C}$; scan mode, 30.0-500.0 (mass range); scan rate, $5000 \mathrm{amu} / \mathrm{s}$, and $3.68 \mathrm{scans} / \mathrm{s}$; start time was $2 \mathrm{~min}$. Electron multiplier (EM) voltage was obtained from autotune. The oven temperature was programmed to hold at $60^{\circ} \mathrm{C}$ for $2 \mathrm{~min}$, increase to $300^{\circ} \mathrm{C}$ at $50{ }^{\circ} \mathrm{C} / \mathrm{min}$, and hold at $300{ }^{\circ} \mathrm{C}$ for $3 \mathrm{~min}$.

To measure the residual limonene in LUVs, a $100 \mu \mathrm{L}$ aliquot is mixed with $1.9 \mathrm{~mL}$ of hexane and $50 \mathrm{mg}$ of $\mathrm{CaSO}_{4}$ (used here to disrupt the LUVs) and stirred for $30 \mathrm{~min}$ to extract limonene. The data were averaged from at least three independent measurements.

\subsubsection{Small-Angle X-ray Scattering (SAXS)}

The structural characteristics of LUVs were studied using small-angle X-ray scattering (SAXS). SAXS patterns were obtained using a Bruker NanoStar instrument equipped with a turbo rotating anode operated at $50 \mathrm{kV}$ and $50 \mathrm{~mA}$, evacuated beam path, two-pinhole collimators, Göbel mirrors selecting $\mathrm{Cu}-\mathrm{K} \alpha$ radiation, and a large 2D Vantec-2000 detector. Samples were measured in $1.5 \mathrm{~mm}$ quartz capillaries; the measurement time was $3 \mathrm{~h}$. Scattering patterns were collected in the range $0.006 \AA-1<\mathrm{q}<0.35 \AA^{-1}$. The sample to detector distance of $67.8 \mathrm{~cm}$ was verified using silver behenate as a calibration standard. The SAXS patterns were corrected for sample transmission and empty cell scattering. Onedimensional (1D) SAXS patterns were obtained by azimuthal integration of the resulting 2D images around the beam center, to obtain the intensity (ISAXS) vs. q profiles. The magnitude of the scattering vector was calculated as $q=(4 \pi / \lambda) \sin \left({ }^{\circ} / 2\right)$, where $\theta$ is the scattering angle and $\lambda$ is the $\mathrm{X}$-ray wavelength for $\mathrm{Cu}-\mathrm{K} \alpha(\lambda=1.5418 \AA)$. 


\subsubsection{Spectroscopic Determination of the Concentration of Xanthophylls}

The concentrations of xanthophylls were measured using a $2 \mathrm{~mm}$ optical path quartz cell in an Agilent Cary $60 \mathrm{UV}$-Vis spectrophotometer. To measure the concentration of xanthophylls in LUVs, a $10 \mu \mathrm{L}$ aliquot is mixed with $300 \mu \mathrm{L}$ of DMF. Standards and samples were measured at least 3 times and the data were averaged. Final concentrations of xanthophylls in LUVs measured by UV/Vis: zeaxanthin $0.038 \mathrm{~g} / \mathrm{L}$ (DPPC/DPPS, $0.45 \mu \mathrm{M}$ final), zeaxanthin $0.14 \mathrm{~g} / \mathrm{L}$ (DMPC/DMPS); lutein $0.0125 \mathrm{~g} / \mathrm{L}$ (DMPC/DMPS, $0.15 \mu \mathrm{M}$ and $0.06 \mu \mathrm{M}$ final); violaxanthin $0.07 \mathrm{~g} / \mathrm{L}$ (DMPC/DMPS, $0.6 \mu \mathrm{M}$ final).

\subsection{BCO2 Protein Palmitoylation Was Analyzed by Acyl-Resin-Assisted Capture (Acyl-RAC)}

For cell lysis and the Acyl-RAC assay, we followed the same protocol as previously described in detail, with slight modifications [34,36]. BCO2-overexpressing HEK293F cells were washed with 1X-PBS and resuspended in lysis buffer (50 mM HEPES (pH 7.4) containing $150 \mathrm{mM} \mathrm{NaCl}, 5 \mathrm{mM}$ EDTA, $1 \%$ glycerol, and $1 \mathrm{X}$ complete protease inhibitor cocktail (Roche Diagnostics)). Resuspended cells were lysed using $\mathrm{N}_{2}$ cavitation followed by centrifugation at $900 \times g$ for $10 \mathrm{~min}$ at $4{ }^{\circ} \mathrm{C}$ to remove the cell debris and nuclei. The clarified supernatant was then subjected to centrifugation at $20,000 \times \mathrm{g}$ for $30 \mathrm{~min}$ at $4{ }^{\circ} \mathrm{C}$ to obtain heavy membrane (mitochondrial) pellet and post-mitochondrial supernatant (light membrane and cytosol) fractions. Typically, a $1000 \mu \mathrm{g}$ amount of resuspended heavy membrane pellet protein (resuspended in lysis buffer containing $0.1 \%$ Triton X-100) was used for palmitoylation detection assay. Briefly, free cysteine sulfhydryl (-SH) groups were blocked with $0.5 \%(v / v)$ S-methyl methanethiosulfonate (MMTS) containing blocking buffer for $15 \mathrm{~min}$ at $40^{\circ} \mathrm{C}$. The blocked protein samples were then subjected to acetone protein precipitation. The protein pellet was then resuspended in $550 \mu \mathrm{L} 100 \mathrm{mM}$ HEPES containing $5 \mathrm{mM}$ EDTA and $1 \%$ SDS $(v / v)$. The samples were then divided into two $250 \mu \mathrm{L}$ aliquots (containing $400 \mu \mathrm{g}$ protein amount) and the remaining $50 \mu \mathrm{L}$ was used as an input. The samples were treated with $250 \mathrm{mM}$ hydroxylamine $\left(\mathrm{NH}_{2} \mathrm{OH}, \mathrm{HAM}\right)$ or control $(250 \mathrm{mM}$ $\mathrm{NaCl}$ ). To capture proteins with free -SH groups, each sample was mixed with $10 \mathrm{mg}$ activated thiol-sepharose $4 \mathrm{~B}$ beads (Sigma) and incubated for $2 \mathrm{~h}$ at room temperature with continuous end-over-end rotation. After incubation, the beads were washed, and bound proteins were eluted by boiling the beads with an aliquot of $50 \mu \mathrm{L}$ elution sample buffer. The input and eluted fractions from "HAM" and "control" samples were separated by SDS-PAGE and analyzed by Western blotting.

\subsection{Immunocolocalization Studies BCO2 Protein in Different Organelles upon Substrate Treatment Using Confocal Microscopy}

BCO2-overexpressing COS7 cells $\left(1 \times 10^{6}\right.$ cells $\left./ \mathrm{mL}\right)$ seeded on poly L-lysine coated $18 \mathrm{~mm}$ coverslips were analyzed by immunofluorescence microscopy to determine the localization of $\mathrm{BCO} 2$ protein in different subcellular organelles as described previously [34]. Briefly, COS7 cells were transfected with $20 \mu \mathrm{g}$ of BCO2-Lumio V5 tag plasmid using Fugene ${ }^{\circledR} 6$ transfection reagent (1:6 DNA: Fugene 6 ratio). After 43 h, BCO2-transfected cells were treated with substrate-encapsulated LUVs for $5 \mathrm{~h}$. Fixed cells were immunostained with V5 monoclonal and polyclonal antibodies alone and together with primary antibodies specific for different subcellular organelles (ER (PDIA3), Golgi (MAN2A1), mitochondria (COX IV and HSP60), and peroxisomes (PMP70)), followed by Alexa fluorophoreconjugated secondary antibodies (Invitrogen). Cell nuclei were stained with DAPI $(1 \mu \mathrm{g} / \mu \mathrm{L}$ solution; Sigma). Slides were then visualized with a Zeiss LSM 700 confocal microscope using a 40X oil immersion lens/1.4-NA and Zeiss ZEN software. Pearson's correlation coefficient values were determined for analysis of the co-localization of $\mathrm{BCO} 2$ protein and different organelles and represented as mean \pm standard deviation. For nuclear colocalization of $\mathrm{BCO} 2$ protein, we measured the Pearson's correlation coefficient of $\mathrm{BCO} 2$ with DAPI-stained nuclei using the results from three independent experiments: single labeling of $\mathrm{BCO} 2$ "alone", double labeling of $\mathrm{BCO} 2$ with mitochondrial markers COX IV and HSP60. Results shown were typical of a minimum of three independent experiments 
with 5-10 fields of view containing on average 1-10 cells/field of view. For quantification and statistical analyses, at least 100 cells were observed for each organelle and nuclear co-localization.

\subsection{Construction of Models and Ligand Docking Simulations}

A model of $\mathrm{mBCO} 2$ was constructed with the Swiss-Model program using the RPE65 $4 \mathrm{~F} 30$ crystal as a template [37]. The loop carrying the PDPCK motif is unresolved in this crystal and is given in this model as a random loop. To model the unresolved areas, the $\mathrm{mBCO} 2$ sequence with distances specified for the catalytic histidines was submitted to the I-Tasser server [38-40]. Five models were obtained; however, the side chains of the Fe-coordinating histidines and glutamates were displaced relative to both the Swiss-Model and RPE65 crystals. The sidechains of the histidines and glutamates of the top I-Tasser model were modified based on the Swiss-Model and the RPE65 crystal structures. Finally, to model an active state, the Fe center and the $\mathrm{O}_{2}$ and $\mathrm{OH}$ of the VP14 crystal (PDB: NPE3) were aligned with both models and integrated into the models. Clashes resulting from the introduction of $\mathrm{O}_{2}$ and $\mathrm{OH}$ on the Fe center were corrected by torsioning the relevant residues. Ligand dockings were carried out using Autodock Vina [41]. In general ligand restraints chosen allowed for all possible torsions.

\section{Results}

\subsection{Xanthophyll Delivery System}

LUVs were prepared by hydration of lipid with carotenoids and assisting limonene, followed by extrusion and extraction of limonene to yield unilamellar vesicles with a narrow size distribution, as confirmed by SAXS and DLS, respectively (Figure 1). The amount of carotenoids associated with LUVs was determined by UV-vis spectroscopy following a previously published protocol [42]. Previously, it was shown that, depending on the structure of the substrate, as well as on the composition of lipids, hydrophobic carotenoids are oriented differently in the phospholipid bilayer of delivery vesicles [43]. Thus, symmetrically oxy-functionalized carotenoids intercalate into phospholipid membranes perpendicular to the membrane surface [44], while fully non-polar $\beta$-carotene is intercalated parallel to the surface within the hydrophobic core of phospholipid bilayers [44,45]. In addition, the molecular length of a carotenoid affects the degree of its intercalation into phospholipid bilayers, depending on the membrane thickness [42]. In fact, zeaxanthin $\left(\mathrm{C}_{40}\right)$ was better incorporated into unilamellar vesicles of dimyristoylphosphatidylcholine $\left(n-C_{14}\right)$, whereas decaprenozeaxanthin $\left(\mathrm{C}_{50}\right)$ was better adopted in unilamellar vesicles of dipalmitoylphosphatidylcholine $\left(\mathrm{n}-\mathrm{C}_{16}\right)$. On the other hand, the inclusion of large hydrophobic molecules into the phospholipid bilayer can change the structure as well as the thickness of vesicles [46]. To understand the membrane structure of vesicles as well as the organization of carotenoids within DMPC and DPPC LUVs with associated zeaxanthin, X-ray scattering measurements were performed. The phosphate-phosphate ( $p-p)$ thicknesses obtained from the SAXS data fit gave values of $\sim 35.1 \AA$ for DMPC-zeaxanthin membranes and $\sim 41.2 \AA$ for DPPC-zeaxanthin membranes, which is the typical thickness for DMPC and DPPC-carotenoid LUVs [42,46]. The length values (Figure 1) of the carotenoid (lutein or zeaxanthin) correspond well to the length of the lipophilic segment of DMPC, but not DPPC. This is the reason for the much weaker incorporation of lutein (or zeaxanthin) into DPPC membranes compared to DMPC [42,47]. 


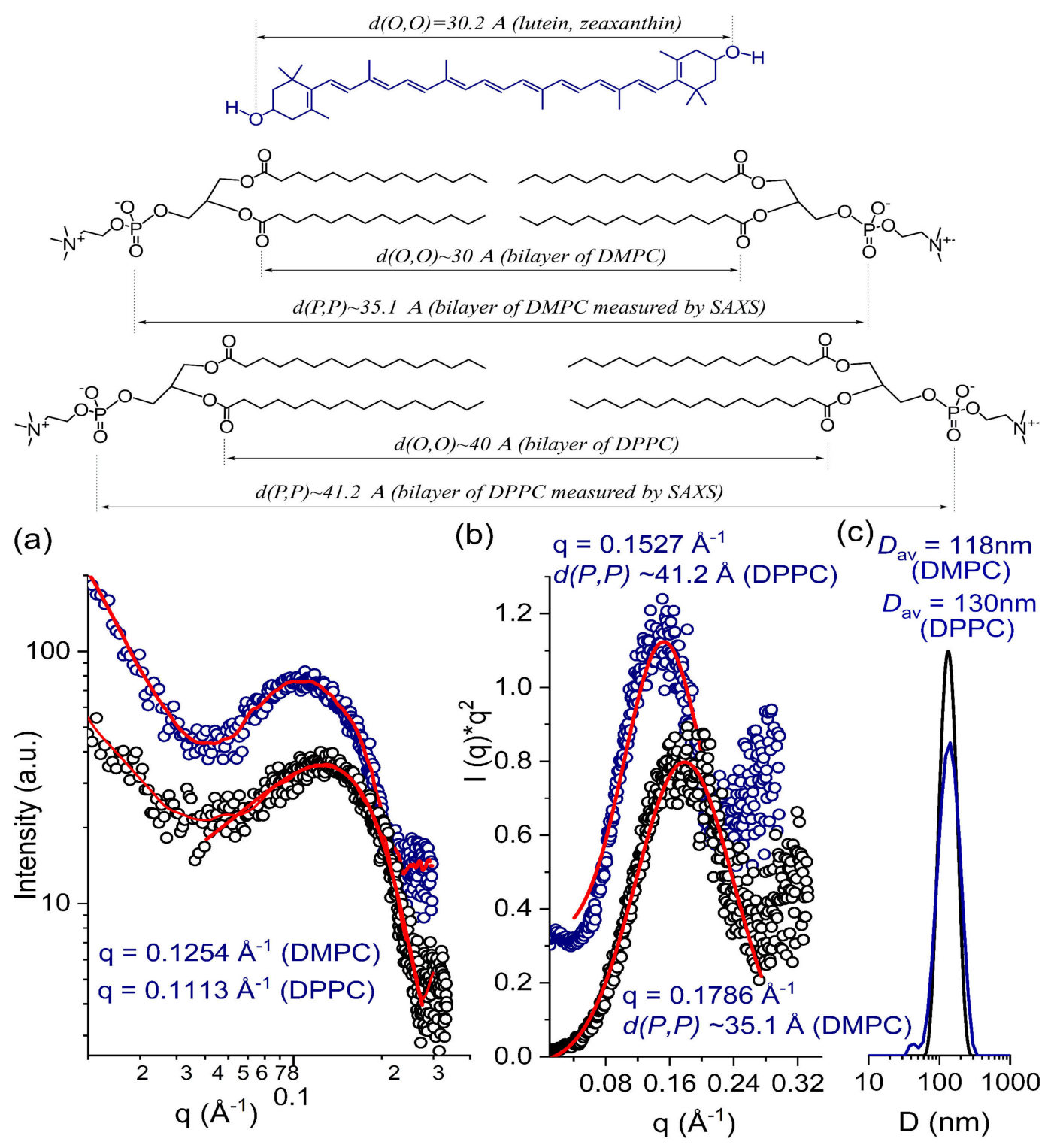

Figure 1. Top: Intramolecular dimensions of carotenoids and DMPC/DPPC bilayer as calculated by molecular mechanics [42,47]. The length of the carotenoid (lutein or zeaxanthin) corresponds to the length of the lipophilic segment of the DMPC phospholipid (double the average distance between the carbonyl group and the methyl group of the DMPC), and does not match the length of the lipophilic segment of the DPPC. Bottom: (a) SAXS data of DMPC-zeaxanthin (black) and DPPC-zeaxanthin (blue) LUVs; (b) Kratky plot from SAXS data, supporting the formation of unilamellar LUVs; and (c) Size distribution and the average diameter of DMPC-zeaxanthin (black) and DPPC-zeaxanthin (blue) LUVs measured by DLS (Figure S1).

\subsection{Palmitoylation of Mouse BCO2 ( $m B C O 2)$ in the Presence of Xanthophylls}

We previously established that $\mathrm{mBCO} 2$ in eukaryotic HEK293F cells is palmitoylated. We discovered that in the presence of the $\mathrm{mBCO} 2$ substrate $\beta$-carotene $\mathrm{mBCO} 2$ loses palmitoylation [34]. Knowing that $\mathrm{BCO} 2$ cleaves xanthophylls $[17,48,49]$ we decided to run palmitoylation assays to study the palmitoylation status of $\mathrm{mBCO} 2$ in the presence of xanthophylls. We first tried to deliver xanthophylls with the detergent Tween 40 [50]. We found that a higher concentration of Tween $40(0.1 \%)$ led to HEK293F cell apoptosis as was previously described for HepG2 cells [51], while a lower concentration (0.01\%) eluted $\mathrm{mBCO} 2$ from membranes during the Acyl-RAC assay even without hydroxylamine treatment (data not shown). Therefore, we established a new method to deliver xantho- 
phylls without detergents using unilamellar LUVs as described above. The content of xanthophylls in the HEK293F cells after $5 \mathrm{~h}$ of treatment was similar to a Tween 40 delivery system in ARPE-19 cells (1-2\%) (Figure S2) [52]. Subsequently, we used the acyl-RAC method as described previously. The membrane fraction of HEK293F cells expressing $\mathrm{mBCO} 2$ was subjected to treatment with hydroxylamine (+HAM) and an equal portion of the fraction was treated with $250 \mathrm{mM} \mathrm{NaCl}(-\mathrm{HAM})$ which served as control. In the absence of substrates, $\mathrm{mBCO} 2$ protein showed an intense protein band in the HAM-treated sample (Figure 2A-D untreated panels, full Western blots are presented in Figure S3), while there was no protein band in the control NaCl-treated sample, indicating S-palmitoylation of $\mathrm{BCO} 2$ protein. In contrast, when cells were pre-treated with $0.15 \mu \mathrm{M}$ lutein and $0.06 \mu \mathrm{M}$ in DMPC/DMPS micelles, no protein band was detected in the HAM-treated sample (Figures 2A,B and S3A,D, lutein panel). Similar results were obtained with DPPC/DPPSencapsulated zeaxanthin $(0.45 \mu \mathrm{M})$ (Figures $2 \mathrm{C}$ and S3B) and DMPC/DMPS-encapsulated violaxanthin $(0.6 \mu \mathrm{M})$ (Figures $2 \mathrm{D}$ and $\mathrm{S3C}$ ).

$\mathbf{A}$

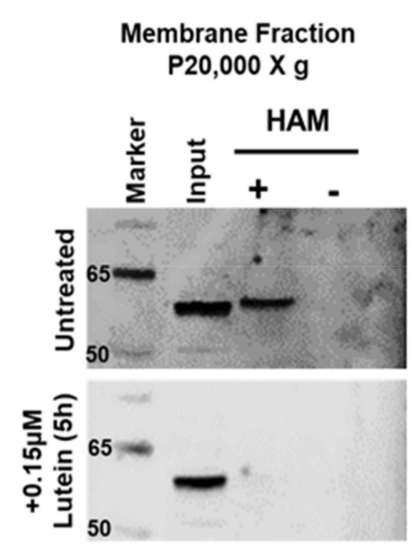

B

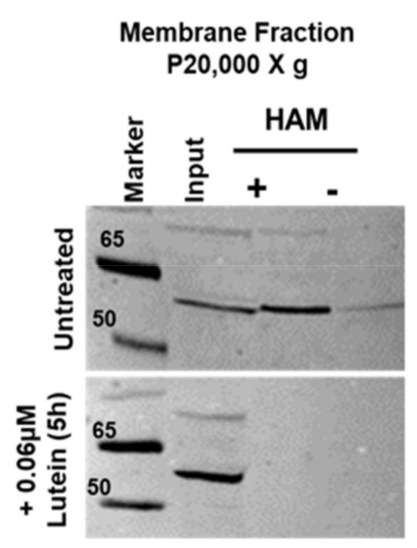

C

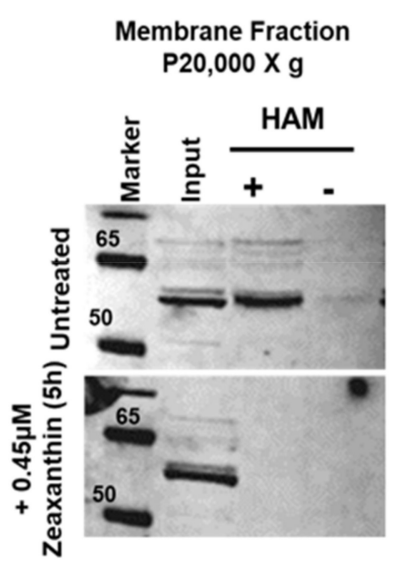

D

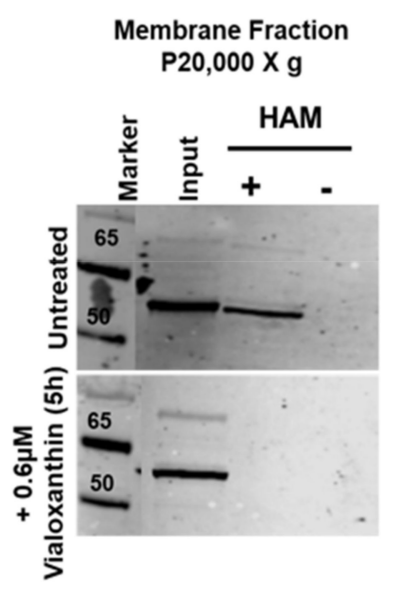

Figure 2. mBCO2 loses its palmitoylation in the presence of substrate. The palmitoylation status of mBCO2 protein was analyzed by Acyl-RAC assay in the presence of different substrates: (A) $0.15 \mu \mathrm{M}$ lutein; (B) $0.06 \mu \mathrm{M}$ lutein; (C) $0.45 \mu \mathrm{M}$ zeaxanthin; and (D) $0.6 \mu \mathrm{M}$ violaxanthin. Equal amounts $(\sim 50 \mu \mathrm{g})$ of the total (indicated as "input") and eluted protein from control (indicated as "-") and hydroxylamine (HAM)-treated (indicated as "+") were subjected to SDS-PAGE and immunoblotting. Western blot results are representative of three independent experiments as shown in the Supplementary figures.

\subsection{Sub-Cellular Localization of $m B C O 2$ with and without Xanthophylls. Shuttling the Enzyme to the Nucleus}

Next, we examined $\mathrm{BCO} 2$ localization by immunofluorescence microscopy using $\mathrm{mBCO} 2$ transfected COS7 cells with various organellar markers (for mitochondria, peroxisomes, endoplasmic reticulum (ER), and Golgi). We confirmed that V5 tag antibodies recognize specifically mBCO2-V5 protein in transfected HEK293F cells (Figure S4). For nuclear labeling, we used DAPI nuclear stain. Immunofluorescence results as shown in Figure 3A (upper left panel) revealed the extensive mitochondrial colocalization with both COXIV and heat-shock protein 60 (HSP60) (Figure 3A, upper left panel). We did not observe any colocalization of $\mathrm{mBCO} 2$ with other organelles (Figure $3 \mathrm{~A}$, bottom left panel, and $4 \mathrm{~B}$ ) as indicated by their low correlation coefficient score compared with mitochondrial localization. Our data are in full agreement with previous results for human BCO2 [21,34]. However, upon addition of substrates to $\mathrm{mBCO} 2$ we observed that a fraction of $\mathrm{mBCO} 2$ colocalizes with the nuclear DAPI stain and the colocalization with mitochondrial markers is significantly decreased (Figure 3A, top right panel, C). The percent of colocalization with nuclear marker is higher when cells are treated with lutein and violaxanthin (Figure $4 \mathrm{~A}-\mathrm{C}$ ) than with zeaxanthin (Figure 5A-C). 

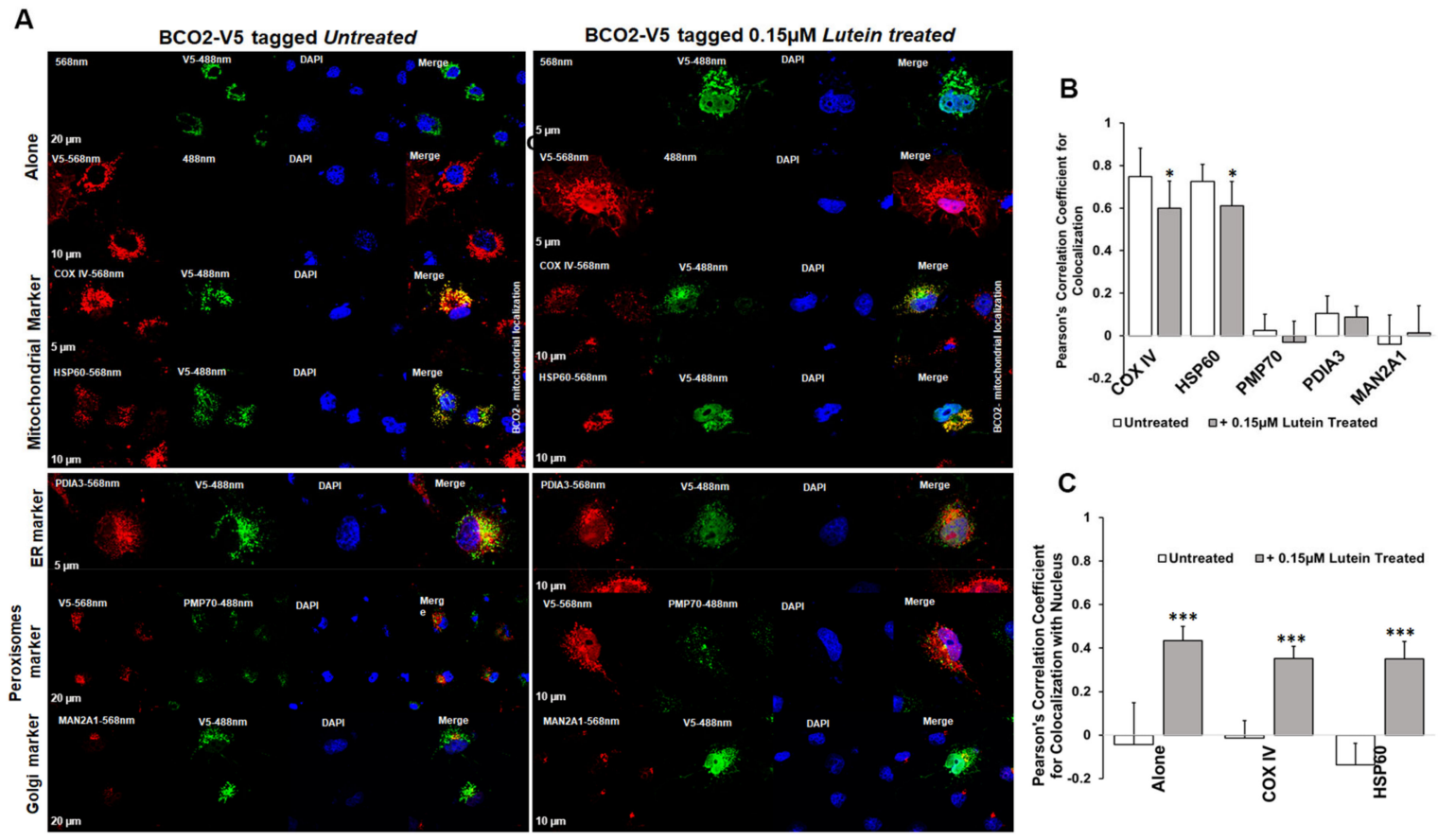

Figure 3. Characterization of subcellular localization of $\mathrm{mBCO} 2$ treated with lutein. (A) COS7 cells expressing $\mathrm{mBCO} 2$ protein treated with $0.15 \mu \mathrm{M}$ lutein for $5 \mathrm{~h}$ were immunoassayed using antibodies against V5 tag and different organelle marker proteins as indicated in the Materials and Methods section. Pearson's correlation coefficient for colocalization of V5-tagged mBCO2 protein with different organellar marker proteins (B) and with nucleus $(\mathbf{C}) ;^{*} p \leq 0.05 ;{ }^{* *} p \leq 0.0005$.
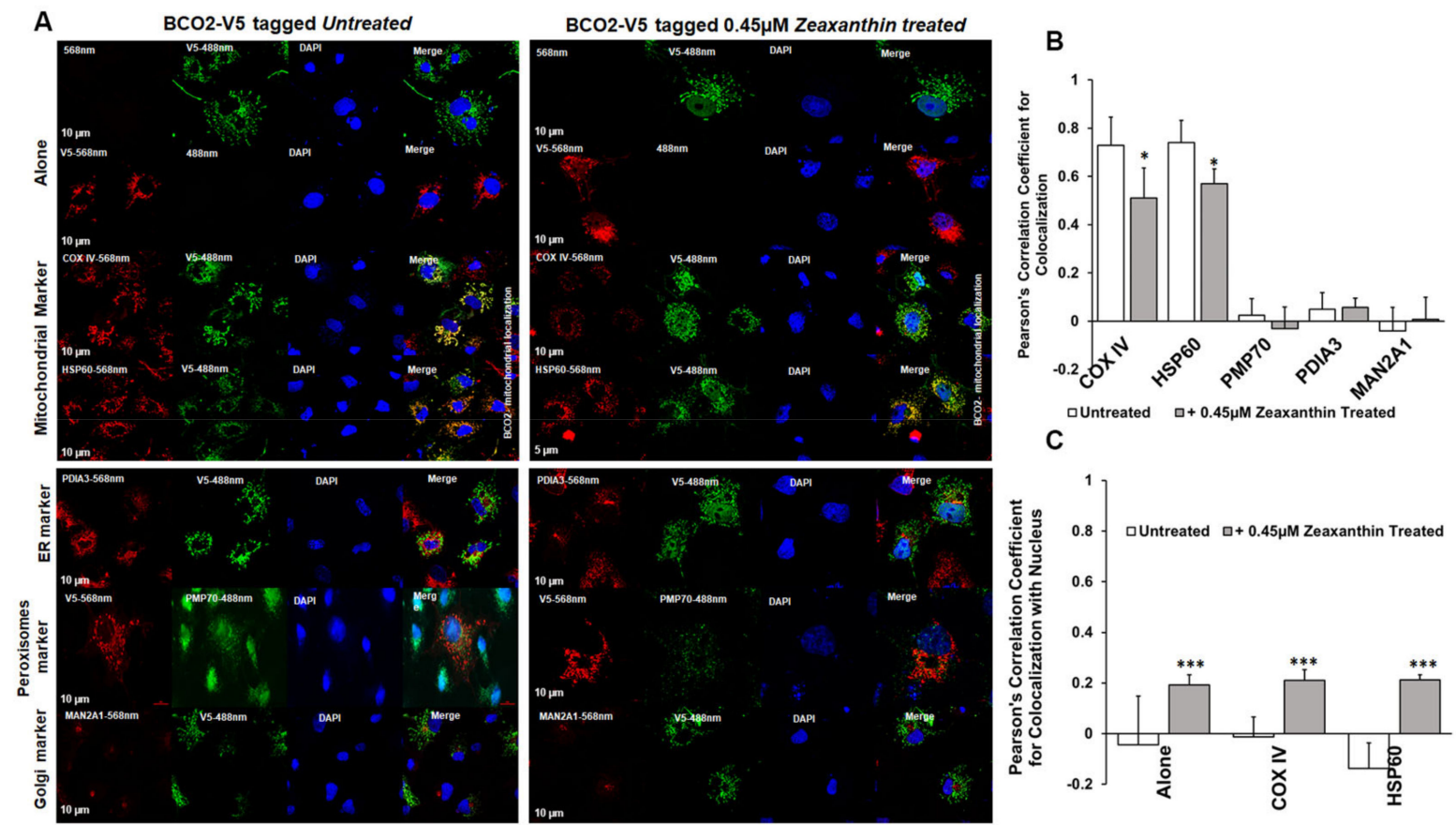

Figure 4. Characterization of subcellular localization of $\mathrm{mBCO} 2$ treated with zeaxanthin. (A) COS7 cells expressing V5tagged mouse BCO2 protein treated with $0.45 \mu \mathrm{M}$ zeaxanthin for $5 \mathrm{~h}$ were immunoassayed using antibodies against V5 tag and different organelle marker proteins as indicated in the Materials and Methods section. Pearson's correlation coefficient $\mathrm{s}$ were calculated for colocalization of V5-tagged $\mathrm{mBCO} 2$ protein with different organellar marker proteins (B) and with nucleus $(\mathbf{C}){ }^{*} p \leq 0.05 ;{ }^{* * *} p \leq 0.0005$. 

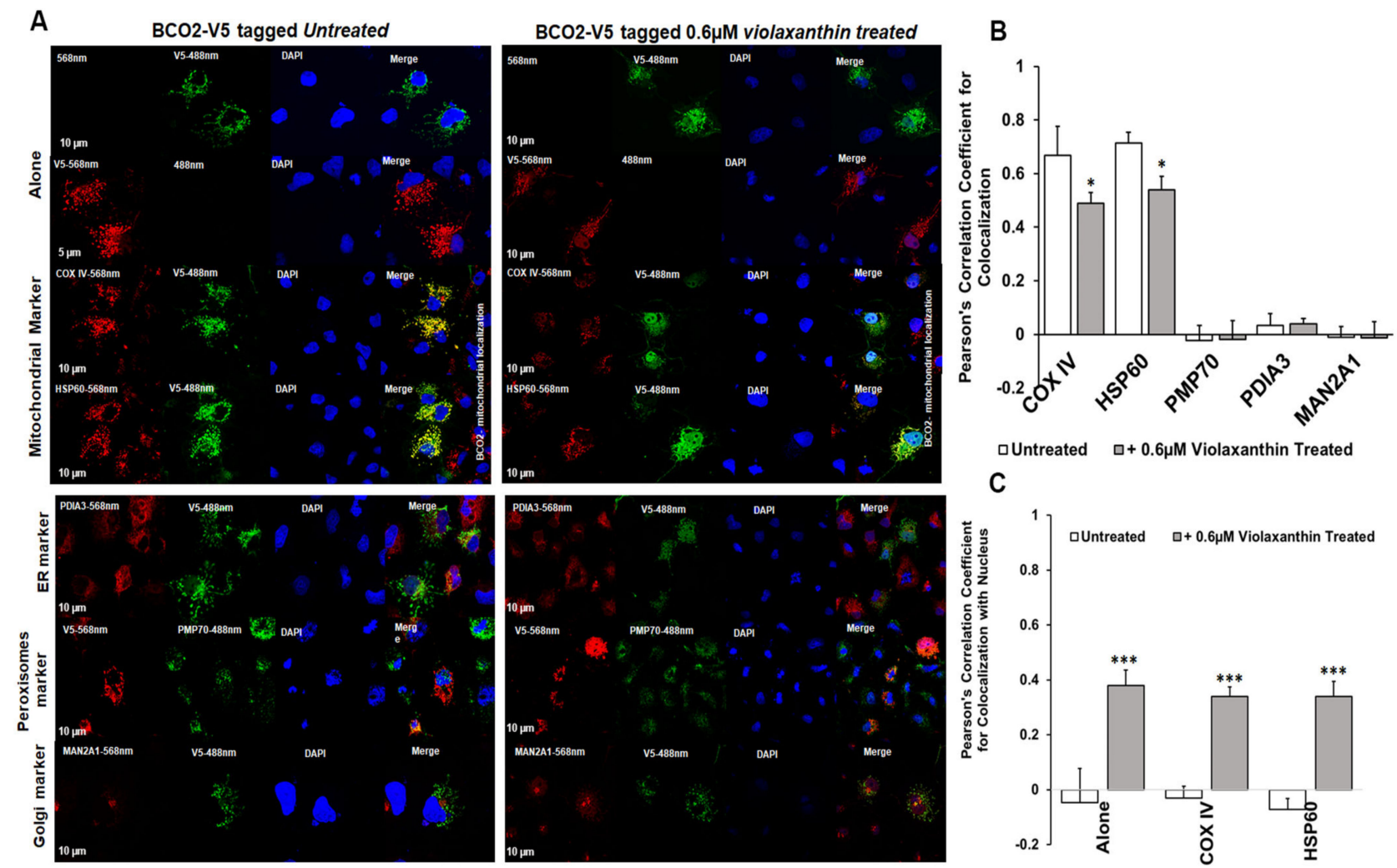

\section{C}

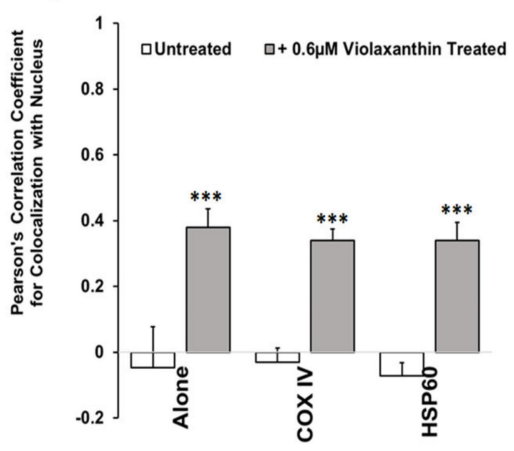

Figure 5. Characterization of subcellular localization of $\mathrm{mBCO} 2$ treated with violaxanthin. (A) COS7 cells expressing $\mathrm{mBCO} 2$ protein treated with $0.6 \mu \mathrm{M}$ violaxanthin for $5 \mathrm{~h}$ were immunoassayed using antibodies against $\mathrm{V} 5$ tag and different organelle marker proteins as indicated in the Materials and Methods section. Pearson's correlation coefficients were calculated for colocalization of V5-tagged $\mathrm{mBCO} 2$ protein with different organellar marker proteins (B) and with nucleus (C); ${ }^{*} p \leq 0.05 ;{ }^{* * *} p \leq 0.0005$.

When we performed the experiment using a lower concentration of lutein $(0.06 \mu \mathrm{M})$ we observed that the percent colocalization of $\mathrm{BCO} 2$ in the nucleus decreased in a lutein concentration-dependent manner (Figure $6 \mathrm{~A}-\mathrm{C}$ ). We have previously observed $\mathrm{mBCO} 2$ colocalization with the nuclear DAPI stain when cells were treated with $\beta$-carotene [34]. It correlates with our observation from the acyl-RAC assay that residual $\mathrm{mBCO} 2$ palmitoylation is seen in some samples in the presence of zeaxanthin, violaxanthin and a low concentration of lutein (Figure S3).

\subsection{Modeling of Xanthophyll Docking in Mouse BCO2}

To understand these findings, we performed modeling of substrate (lutein, zeaxanthin and violaxanthin) docking in $\mathrm{mBCO} 2$. The Swiss-Model random coil model of the bovine RPE65 4F30 crystal with the helical -PDPCK- containing loop modeled in (using I-TASSER as described in Methods) was used as a basis to model mBCO2. We observed the highest binding energy to the Swiss-Model model of $\mathrm{mBCO} 2$ protein with lutein and the lowest with zeaxanthin. However, zeaxanthin binding energy significantly increased in Model1 (clash-free I-TASSER model which corrected the catalytic $\mathrm{H}$ and $\mathrm{E}$ residues orientation from the Swiss-Model model) docking simulation, while lutein and violaxanthin binding energy did not change (Table 1). Additionally, zeaxanthin did not line up well in the $\mathrm{mBCO} 2$ active site and curled up in both of the models (Figure 7A,B). 

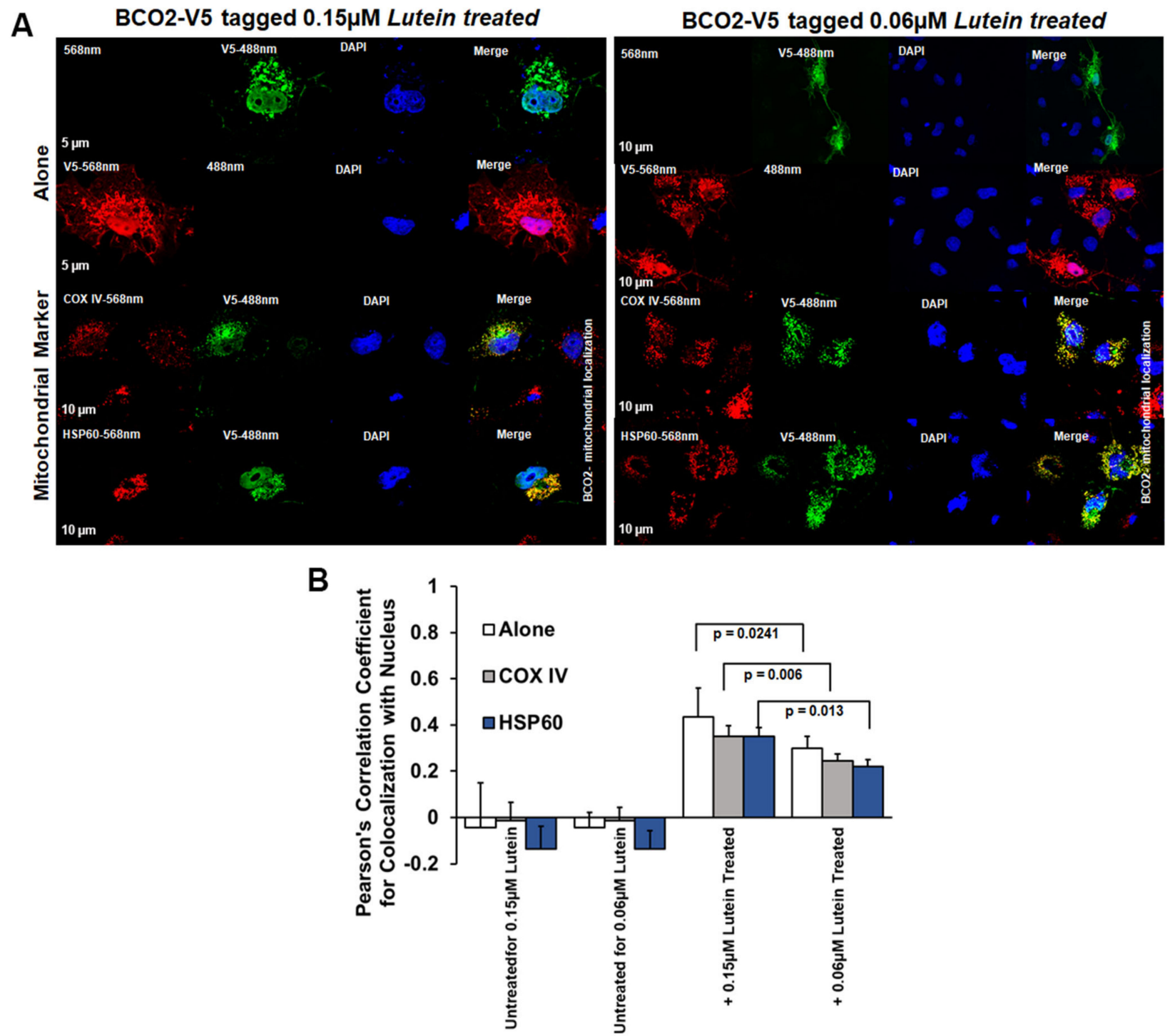

Figure 6. (A) Cellular Localization of V5-tagged mouse $\mathrm{BCO} 2$ with and without lutein: $\mathrm{mBCO} 2$ with and without $0.15 \mu \mathrm{M}$ lutein; (left panel) $\mathrm{mBCO} 2$ with and without $0.06 \mu \mathrm{M}$ lutein; (right panel). Pearson's correlation coefficients were calculated for colocalization of V5-tagged $\mathrm{mBCO} 2$ protein with nucleus (B).

Table 1. AutoDock Vina modeling of the affinity of carotenoids to mBCO2. The lowest (best) docking energy is used.

\begin{tabular}{ccc}
\hline Carotenoid & SwissPro Model & I-TASSER Model1 \\
\hline violaxanthin & -11.0 & -10.8 \\
zeaxanthin & -11.8 & -10.1 \\
lutein & -10.5 & -10.4 \\
$\beta$-carotene & -11.8 & -10.6 \\
\hline
\end{tabular}




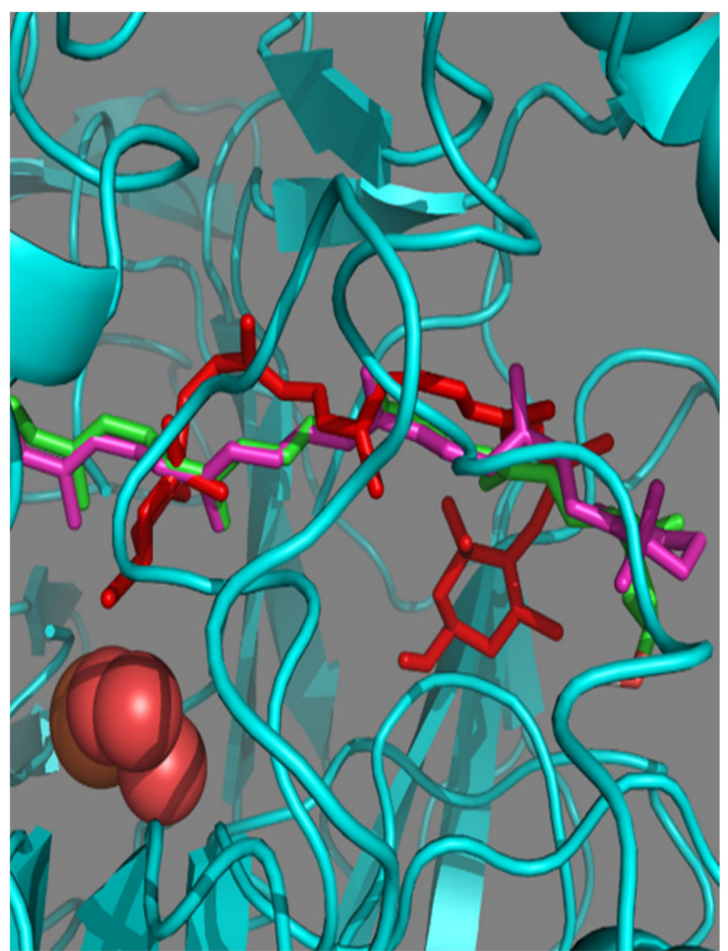

(A)

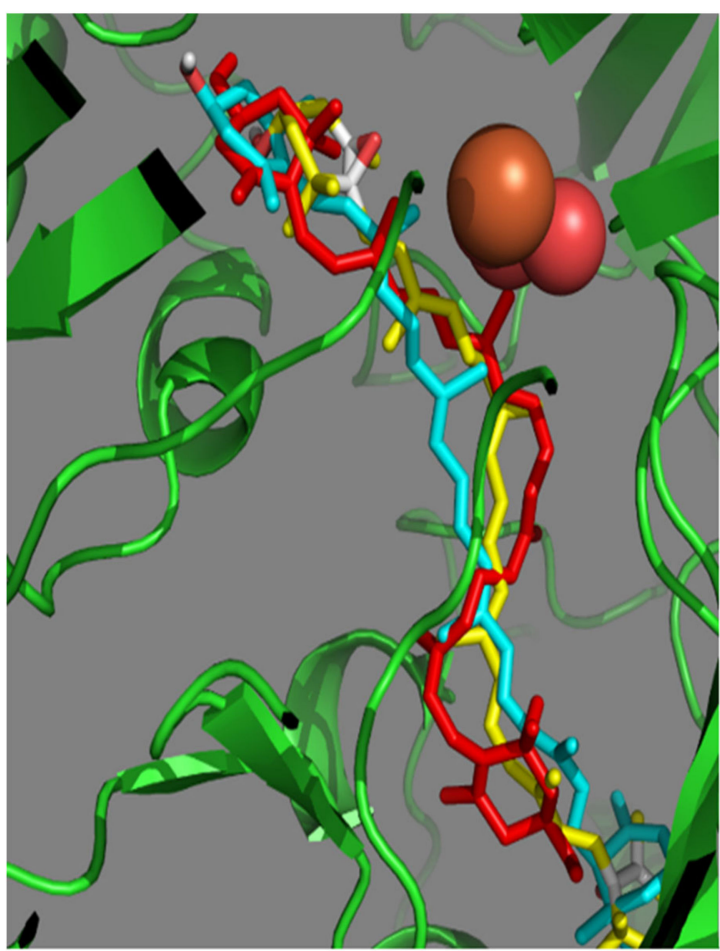

(B)

Figure 7. Visualization of carotenoid docking $(\mathbf{A})$ on the $\mathrm{mBCO} 2$ protein I-TASSER model (lutein in green and $\beta$-carotene in purple, zeaxanthin in red and protein in cyan) and (B) on the $\mathrm{mBCO} 2$ protein Swiss-Model model (violaxanthin in yellow, lutein in cyan, zeaxanthin in red and protein in green).

\section{Discussion}

Here we show that xanthophylls affect the palmitoylation status of $\mathrm{mBCO} 2$ and direct translocation of the enzyme to the nucleus where xanthophylls could modulate gene expression and exert antioxidant properties through activation of cellular oxidative stress response genes. To accomplish this, we developed a new unique non-disruptive way for membranes to deliver xanthophylls to cells. Thus, we produced LUVs with xanthophylls by using limonene to assist solubilization of the xanthophyll in bilayers made of phospholipids of the appropriate size. Our findings expand our previous findings regarding substrateinduced depalmitoylation and organellar relocalization of $\mathrm{mBCO} 2[34]$ and suggest a common effect of carotenoids on this enzyme.

The catalytic activity of $\mathrm{mBCO} 2$ towards certain oxidative metabolites of zeaxanthin was recently documented [17]. There are numerous other xanthophylls in the human diet. For example, violaxanthin is a diepoxy derivative of zeaxanthin and accumulates in a significant amount in human ovaries [53]. However, it was not known if it is a substrate and if $\mathrm{mBCO} 2$ could cleave it. Our results suggest that it does. It will be useful to better understand substrate structural requirements for $\mathrm{mBCO} 2$ function in cells.

Xanthophylls are well known for their antioxidant protective properties which may play a role in delaying chronic diseases. Despite this, it is still far from clear how xanthophylls exert the full extent of their antioxidant properties [54]. A widely proposed pathway is that they dissipate excess energy from potentially harmful oxidants, such as excited triplet states of singlet oxygen, by virtue of their extended conjugated bond systems and thereby protect membranes from oxidant stress [11]. Recently, however, a body of literature has begun to accumulate, pointing to direct regulation of gene expression by xanthophylls $[50,55]$. This would be analogous to the role of $\beta$-carotene metabolites in transcriptional regulation: $\beta$-apocarotenoids have been recently found to function as transcriptional regulators, specifically as nuclear receptor antagonists, which inhibit retinoic acid activities [56-59]. 
In this regard, lutein has been shown to activate Nrf2, an emerging regulator of cellular resistance to oxidants, and to affect Nrf2 pathway genes in retinal cells [50,60]. It has been demonstrated that lutein effectively protects ARPE-19 from damage generated by hyperglycemia by activating Nrf2 through its regulators, suggesting a preventive role of lutein against diabetic retinopathy [60]. How lutein (and other carotenoids/carotenoid metabolites) might enter the nucleus occurs is currently unknown.

In this respect, we previously described that presence of $\beta$-carotene changes the palmitoylation status of $\mathrm{mBCO} 2$ and that we can see residual colocalization with the nucleus [34]. Thus, our results with lutein, zeaxanthin and violaxanthin extend these prior findings by demonstrating that, generally, $\mathrm{mBCO} 2$ is palmitoylated in the absence of substrates and that it loses palmitoylation when substrates are present in the cells. Therefore, it prompts us to propose that loss of palmitoylation upon substrate-treatment somehow influences the $\mathrm{BCO} 2$-mitochondrial localization and promotes the shuttling of $\mathrm{BCO} 2$ to the nucleus. The mechanism of substrate bound-BCO2 shuttling to the nucleus is still unclear and needs to be investigated in further detail to explore the unclear function of $\mathrm{BCO} 2$ in the nucleus. Differences in binding of substrates to $\mathrm{mBCO} 2$ as demonstrated in our molecular docking experiments could define differences in nucleus shuttling and antioxidant effect of the various xanthophylls. Additionally, it is important to further study if $\mathrm{mBCO} 2$ could work as a transporter of xanthophylls and their metabolites to the nucleus (in addition to $\beta$-carotene and its metabolites), and to elucidate the potential mode of action of xanthophylls and their enzymatic metabolites on gene expression in relation to an oxidative stress response, in addition to their quenching properties.

Supplementary Materials: The following are available online at https://www.mdpi.com/20763921/10/3/413/s1, Figure S1: DLS data for LUVs with xanthophylls; Figure S2: Detection of mouse $\mathrm{BCO} 2$ palmitoylation by acyl-RAC assays. Raw Western blots; Figure S3: $\mathrm{mBCO} 2$ protein expression in the COS7 cells transfected with V5-tagged $\mathrm{mBCO}$. COS7 cells expressing $\mathrm{mBCO} 2$ protein treated with different substrates for $5 \mathrm{~h}$ were grown on poly L-lysine coated coverslips and subjected to immunolocalization studies using confocal microscopy. For immunoblotting, post-nuclear supernatant was separated by SDS-PAGE. The presence of V5-tagged $\mathrm{mBCO} 2$ was probed by immunoblotting with rabbit polyclonal anti-mouse $\mathrm{BCO} 2$ (green) and mouse monoclonal anti-V5 (red) antibodies.

Author Contributions: Conceptualization, E.P. (Eugenia Poliakov); Methodology, S.U., E.P. (Eugenia Poliakov), S.A.D., W.Z., E.P. (Eugene Pinkhassik); formal analysis, S.U., S.A.D., E.P. (Eugenia Poliakov); resources, T.M.R., E.P. (Eugene Pinkhassik); data curation, modeling, docking S.G.; writing — original draft preparation, E.P. (Eugene Pinkhassik), S.A.D., S.U.; writing—review and editing, E.P. (Eugenia Poliakov), E.P. (Eugene Pinkhassik), S.A.D. and T.M.R. All authors have read and agreed to the published version of the manuscript.

Funding: This research was funded by the Intramural Research Program of the National Eye Institute, NIH (T.M. Redmond) and by the National Science Foundation (CHE-1709921; E. Pinkhassik).

Institutional Review Board Statement: Not applicable.

Informed Consent Statement: Not applicable.

Data Availability Statement: The data presented in this study are available in this article and Supplementary Material here.

Acknowledgments: Access to vSANS and NSE instruments was provided by the Center for HighResolution Neutron Scattering, a partnership between the National Institute of Standards and Technology and the National Science Foundation under Agreement No. DMR-2010792. We acknowledge the support of the National Institute of Standards and Technology, U.S. Department of Commerce, in providing the neutron research facilities used in this work.

Conflicts of Interest: The authors declare no conflict of interest. 


\section{References}

1. Bernstein, P.S.; Li, B.; Vachali, P.P.; Gorusupudi, A.; Shyam, R.; Henriksen, B.S.; Nolan, J.M. Lutein, zeaxanthin, and mesozeaxanthin: The basic and clinical science underlying carotenoid-based nutritional interventions against ocular disease. Prog. Retin. Eye Res. 2016, 50, 34-66. [CrossRef] [PubMed]

2. Nolan, J.M.; Mulcahy, R.; Power, R.; Moran, R.; Howard, A.N. Nutritional Intervention to Prevent Alzheimer's Disease: Potential Benefits of Xanthophyll Carotenoids and Omega-3 Fatty Acids Combined. J. Alzheimer's Dis. 2018, 64, 367-378. [CrossRef] [PubMed]

3. Bone, A.R.; Landrum, J.T.; Fernandez, L.; Tarsis, S.L. Analysis of the macular pigment by HPLC: Retinal distribution and age study. Investig. Ophthalmol. Vis. Sci. 1988, 29, 843-849.

4. Johnson, E.J.; Vishwanathan, R.; Johnson, M.A.; Hausman, D.B.; Davey, A.; Scott, T.M.; Green, R.C.; Miller, L.S.; Gearing, M.; Woodard, J.; et al. Relationship between Serum and Brain Carotenoids, alpha-Tocopherol, and Retinol Concentrations and Cognitive Perfor-mance in the Oldest Old from the Georgia Centenarian Study. J. Aging Res. 2013, 2013, 951786. [CrossRef] [PubMed]

5. Rapp, L.M.; Maple, S.S.; Choi, J.H. Lutein and zeaxanthin concentrations in rod outer segment membranes from perifoveal and peripheral human retina. Investig. Ophthalmol. Vis. Sci. 2000, 41, 1200-1209.

6. Widomska, J.; Subczynski, W.K. Mechanisms enhancing the protective functions of macular xanthophylls in the retina during oxidative stress. Exp. Eye Res. 2019, 178, 238-246. [CrossRef]

7. Grudzinski, W.; Nierzwicki, L.; Welc, R.; Reszczynska, E.; Luchowski, R.; Czub, J.; Gruszecki, W.I. Localization and Orientation of Xanthophylls in a Lipid Bilayer. Sci. Rep. 2017, 7, 1-10. [CrossRef]

8. Gruszecki, W.I.; Strzałka, K. Carotenoids as modulators of lipid membrane physical properties. Biochim. Biophys. Acta BBA Mol. Basis Dis. 2005, 1740, 108-115. [CrossRef] [PubMed]

9. Widomska, J.; Zareba, M.; Subczynski, W.K. Can Xanthophyll-Membrane Interactions Explain Their Selective Presence in the Retina and Brain? Foods 2016, 5, 7. [CrossRef] [PubMed]

10. Delmelle, M. An Investigation of Retinal as a Source of Singlet Oxygen. Photochem. Photobiol. 1978, 27, 731-734. [CrossRef]

11. Kim, S.R.; Nakanishi, K.; Itagaki, Y.; Sparrow, J.R. Photooxidation of A2-PE, a photoreceptor outer segment fluorophore, and pro-tection by lutein and zeaxanthin. Exp. Eye Res. 2006, 82, 828-839. [CrossRef] [PubMed]

12. Mortensen, A.; Skibsted, L.H. Free radical transients in photobleaching of xanthophylls and carotenes. Free Radic. Res. 1997, 26, 549-563. [CrossRef] [PubMed]

13. Adams, D.B.; Pozo, L.M.; Stewart, J.J.; Adams, W.W., 3rd. Zeaxanthin and Lutein: Photoprotectors, Anti-Inflammatories, and Brain Food. Molecules 2020, 25, 3607. [CrossRef]

14. Connor, W.E.; Duell, P.B.; Kean, R.; Wang, Y. The Prime Role of HDL to Transport Lutein into the Retina: Evidence from HDL-Deficient WHAM Chicks Having a Mutant ABCA1 Transporter. Investig. Opthalmol. Vis. Sci. 2007, 48, 4226-4231. [CrossRef]

15. Loane, E.; Nolan, J.M.; Donovan, O.O.; Bhosale, P.; Bernstein, P.S.; Beatty, S. Transport and Retinal Capture of Lutein and Zeaxanthin with Reference to Age-related Macular Degeneration. Surv. Ophthalmol. 2008, 53, 68-81. [CrossRef]

16. Li, B.; Vachali, P.; Frederick, J.M.; Bernstein, P.S. Identification of StARD3 as a Lutein-Binding Protein in the Macula of the Primate Retina. Biochemistry 2011, 50, 2541-2549. [CrossRef] [PubMed]

17. Thomas, L.D.; Bandara, S.; Parmar, V.M.; Srinivasagan, R.; Khadka, N.; Golczak, M.; Kiser, P.D.; von Lintig, J. The human mitochondrial enzyme BCO2 exhibits catalytic activity toward carotenoids and apocarotenoids. J. Biol. Chem. 2020, 295, 15553-15565. [CrossRef] [PubMed]

18. Kiefer, C.; Hessel, S.; Lampert, J.M.; Vogt, K.; Lederer, M.O.; Breithaupt, D.E.; Von Lintig, J. Identification and Characterization of a Mammalian Enzyme Catalyzing the Asymmetric Oxidative Cleavage of Provitamin A. J. Biol. Chem. 2001, $276,14110-14116$. [CrossRef] [PubMed]

19. Amengual, J.; Lobo, G.P.; Golczak, M.; Li, H.N.M.; Klimova, T.; Hoppel, C.L.; Wyss, A.; Palczewski, K.; Von Lintig, J. A mitochondrial enzyme degrades carotenoids and protects against oxidative stress. FASEB J. 2010, 25, 948-959. [CrossRef]

20. Lobo, G.P.; Isken, A.; Hoff, S.; Babino, D.; Von Lintig, J. BCDO2 acts as a carotenoid scavenger and gatekeeper for the mitochondrial apoptotic pathway. Development 2012, 139, 2966-2977. [CrossRef]

21. Palczewski, G.; Amengual, J.; Hoppel, C.L.; Von Lintig, J. Evidence for compartmentalization of mammalian carotenoid metabolism. FASEB J. 2014, 28, 4457-4469. [CrossRef]

22. Lindqvist, A.; He, Y.G.; Andersson, S. Cell type-specific expression of beta-carotene $9^{\prime}, 10^{\prime}$-monooxygenase in human tissues. J. Histochem. Cytochem. 2005, 53, 1403-1412. [CrossRef]

23. Wu, L.; Guo, X.; Wang, W.; Medeiros, D.M.; Clarke, S.L.; Lucas, E.A.; Smith, B.J.; Lin, D. Molecular aspects of beta, beta-carotene-9', 10'-oxygenase 2 in carotenoid metabolism and diseases. Exp. Biol. Med. 2016, 241, 1879-1887. [CrossRef] [PubMed]

24. Våge, I.D.; A Boman, I. A nonsense mutation in the beta-carotene oxygenase 2 (BCO2) gene is tightly associated with accumulation of carotenoids in adipose tissue in sheep (Ovis aries). BMC Genet. 2010, 11, 10. [CrossRef]

25. Berry, S.D.; Davis, S.R.; Beattie, E.M.; Thomas, N.L.; Burrett, A.K.; Ward, H.E.; Stanfield, A.M.; Biswas, M.; Udy, A.A.E.; Oxley, P.E.; et al. Mutation in bovine beta-carotene oxygenase 2 affects milk color. Genetics 2009, 182, 923-926. [CrossRef]

26. Eriksson, J.; Larson, G.; Gunnarsson, U.; Bed’hom, B.; Boichard, T.M.; Stromstedt, L.; Wright, D.; Jungerius, A.; Vereijken, A.; Randi, E.; et al. Identification of the yellow skin gene reveals a hybrid origin of the domestic chicken. PLoS Genet. $2008,4$. [CrossRef] 
27. Meyers, K.J.; Mares, J.A.; Igo, R.P.; Truitt, B.; Liu, Z.; Millen, A.E.; Klein, M.L.; Johnson, E.J.; Engelman, C.D.; Karki, C.K.; et al. Genetic Evidence for Role of Carotenoids in Age-Related Macular Degeneration in the Carotenoids in Age-Related Eye Disease Study (CAREDS). Investig. Opthalmol. Vis. Sci. 2014, 55, 587-599. [CrossRef] [PubMed]

28. Guo, X.; Wu, L.; Lyu, Y.; Chowanadisai, W.; Clarke, S.L.; Lucas, E.A.; Smith, B.J.; He, H.; Wang, W.; Medeiros, D.M.; et al. Ablation of be-ta,beta-carotene- $9^{\prime}, 10^{\prime}$-oxygenase 2 remodels the hypothalamic metabolome leading to metabolic disorders in mice. J. Nutr. Biochem. 2017, 46, 74-82. [CrossRef]

29. Babino, D.; Palczewski, G.; Adhi, W.M.A.; Kiser, P.D.; Golczak, M.; von Lintig, J. Characterization of the Role of beta-Carotene 9,10-Dioxygenase in Macular Pigment Metabolism. J. Biol. Chem. 2015, 290, 24844-24857. [CrossRef] [PubMed]

30. Li, B.; Vachali, P.P.; Gorusupudi, A.; Shen, Z.; Sharifzadeh, H.; Besch, B.M.; Nelson, K.; Horvath, M.M.; Frederick, J.M.; Baehr, W. Inactivity of human beta, beta-carotene-9',10'-dioxygenase (BCO2) underlies retinal accumulation of the human macular ca-rotenoid pigment. Proc. Natl. Acad. Sci. USA 2014, 111, 10173-10178. [CrossRef] [PubMed]

31. Poliakov, E.; Soucy, J.; Gentleman, S.; Rogozin, I.B.; Redmond, T.M. Phylogenetic analysis of the metazoan carotenoid oxygenase superfamily: A new ancestral gene assemblage of BCO-like (BCOL) proteins. Sci. Rep. 2017, 7, 3192. [CrossRef] [PubMed]

32. Dergunov, S.A.; Bowles, E.A.; Gordon, W.R.; Green, M.; Bierman, A.; Ellsworth, M.L.; Pinkhassik, E.; Sprague, R.S. Liposomal delivery of a phosphodiesterase 3 inhibitor rescues low oxygen-induced ATP release from erythrocytes of humans with type 2 diabetes. Biochem. Biophys. Rep. 2015, 2, 137-142. [CrossRef]

33. Scott, H.L.; Skinkle, A.; Kelley, E.G.; Waxham, M.N.; Levental, I.; Heberle, F.A. On the Mechanism of Bilayer Separation by Extrusion, or Why Your LUVs Are Not Really Unilamellar. Biophys. J. 2019, 117, 1381-1386. [CrossRef] [PubMed]

34. Uppal, S.; Rogozin, I.B.; Redmond, T.; Poliakov, E. Palmitoylation of Metazoan Carotenoid Oxygenases. Molecules 2020, $25,1942$. [CrossRef]

35. Redmond, T.M.; Poliakov, E.; Yu, S.; Tsai, J.-Y.; Lu, Z.; Gentleman, S. Mutation of key residues of RPE65 abolishes its enzymatic role as isomerohydrolase in the visual cycle. Proc. Natl. Acad. Sci. USA 2005, 102, 13658-13663. [CrossRef] [PubMed]

36. Uppal, S.; Liu, T.; Poliakov, E.; Gentleman, S.; Redmond, T.M. The dual roles of RPE65 S-palmitoylation in membrane association and visual cycle function. Sci. Rep. 2019, 9, 5218. [CrossRef] [PubMed]

37. Waterhouse, A.; Bertoni, M.; Bienert, S.; Studer, G.; Tauriello, G.; Gumienny, R.; Heer, F.T.; de Beer, T.A.P.; Rempfer, C.; Bordoli, L.; et al. SWISS-MODEL: Homology modelling of protein structures and complexes. Nucleic Acids Res. 2018, 46, W296-W303. [CrossRef]

38. Roy, A.; Kucukural, A.; Zhang, Y. I-TASSER: A unified platform for automated protein structure and function prediction. Nat. Protoc. 2010, 5, 725-738. [CrossRef]

39. Roy, A.; Yang, J.; Zhang, Y. COFACTOR: An accurate comparative algorithm for structure-based protein function annotation. Nucleic Acids Res. 2012, 40, W471-W477. [CrossRef]

40. Zhang, Y. I-TASSER server for protein 3D structure prediction. BMC Bioinform. 2008, 9, 1-8. [CrossRef]

41. Trott, O.; Olson, A.J. AutoDock Vina: Improving the speed and accuracy of docking with a new scoring function, efficient op-timization, and multithreading. J. Comput. Chem. 2010, 31, 455-461. [CrossRef] [PubMed]

42. Lazrak, T.; Milon, A.; Wolff, G.; Albrecht, A.M.; Miehe, M.; Ourisson, G.; Nakatani, Y. Comparison of the effects of inserted C40and C50-terminally dihydroxylated carotenoids on the mechanical properties of various phospholipid vesicles. Biochim. Biophys. Acta (BBA) Biomembr. 1987, 903, 132-141. [CrossRef]

43. Nacke, C.; Schrader, J. Liposome based solubilisation of carotenoid substrates for enzymatic conversion in aqueous media. J. Mol. Catal. B Enzym. 2011, 71, 133-138. [CrossRef]

44. Socaciu, C.; Jessel, R.; Diehl, H.A. Carotenoid incorporation into microsomes: Yields, stability and membrane dynamics. Spectrochim. Acta Part A Mol. Biomol. Spectrosc. 2000, 56, 2799-2809. [CrossRef]

45. Strzałka, K.; Gruszecki, W.I. Effect of $\beta$-carotene on structural and dynamic properties of model phosphatidylcholine membranes. I. An EPR spin label study. Biochimica et Biophysica Acta (BBA) Biomembranes 1994, 1194, 138-142. [CrossRef]

46. Chakraborty, S.; Doktorova, M.; Molugu, T.R.; Heberle, F.A.; Scott, H.L.; Dzikovski, B.; Nagao, M.; Stingaciu, L.-R.; Standaert, R.F.; Barrera, F.N.; et al. How cholesterol stiffens unsaturated lipid membranes. Proc. Natl. Acad. Sci. USA 2020, 117, 21896-21905. [CrossRef]

47. Milon, A.; Ourisson, G.; Nakatani, Y. Organization of Carotenoid-Phospholipid Bilayer Systems. Incorporation of Zeaxanthin, Astaxanthin, and their C50 Homologues into Dimyristoylphosphatidylcholine Vesicles. Helv. Chim. Acta 1986, 69, 12-24. [CrossRef]

48. Dela Sena, C.; Sun, J.; Narayanasamy, S.; Riedl, K.M.; Yuan, Y.; Curley, R.W., Jr.; Schwartz, S.J.; Harrison, E.H. Substrate Specificity of Purified Recombinant Chicken beta-Carotene 9',10'-Oxygenase (BCO2). J. Biol. Chem. 2016, 291, 14609-14619. [CrossRef] [PubMed]

49. Babino, D.; Golczak, M.; Kiser, P.D.; Wyss, A.; Palczewski, K.; von Lintig, J. The Biochemical Basis of Vitamin A3 Production in Ar-thropod Vision. ACS Chem. Biol. 2016, 11, 1049-1057. [CrossRef] [PubMed]

50. Frede, K.; Ebert, F.; Kipp, A.P.; Schwerdtle, T.; Baldermann, S. Lutein Activates the Transcription FactorNrf2in Human Retinal Pigment Epithelial Cells. J. Agric. Food Chem. 2017, 65, 5944-5952. [CrossRef]

51. Saadatmandi, B.C.; Rimbach, G.; Jungblut, A.; Frank, J. Comparison of tetrahydrofuran, fetal calf serum, and Tween 40 for the delivery of astaxanthin and canthaxanthin to HepG2 cells. Cytotechnology 2010, 63, 89-97. [CrossRef] 
52. During, A.; Doraiswamy, S.; Harrison, E.H. Xanthophylls are preferentially taken up compared with beta-carotene by retinal cells via a SRBI-dependent mechanism. J. Lipid Res. 2008, 49, 1715-1724. [CrossRef] [PubMed]

53. Semeniuk, C.E.; Wolczynski, S. Identification of carotenoids in ovarian tissue in women. Oncol. Rep. 2005, 14, 1385-1392. [CrossRef]

54. Perlman, M.J.A.; Millen, A.E.; Ficek, T.L.; Hankinson, S.E. The body of evidence to support a protective role for lutein and ze-axanthin in delaying chronic disease. Overview. J. Nutr. 2002, 132, 518S-524S. [CrossRef] [PubMed]

55. Li, R.; Turner, S.D.; Brautigan, D.L. Xanthophylls lutein and zeaxanthin modify gene expression and induce synthesis of hyaluronan in keratinocyte model of human skin. Biochem. Biophys. Rep. 2015, 4, 52-58. [CrossRef]

56. Eroglu, A.; Hruszkewycz, D.P.; Curley, R.W.; Harrison, E.H., Jr. The eccentric cleavage product of beta-carotene, be-ta-apo-13carotenone, functions as an antagonist of RXRalpha. Arch. Biochem. Biophys. 2010, 504, 11-16. [CrossRef] [PubMed]

57. Eroglu, A.; Hruszkewycz, D.P.; dela Sena, C.; Narayanasamy, S.; Riedl, K.M.; Kopec, R.E.; Schwartz, S.J.; Curley, R.W., Jr.; Harrison, E.H. Naturally occurring eccentric cleavage products of provitamin A beta-carotene function as antagonists of retinoic acid receptors. J. Biol. Chem. 2012, 287, 15886-15895. [CrossRef]

58. Wang, C.X.; Jiang, H.; Yuen, J.J.; Lee, S.A.; Narayanasamy, S.; Curley, R.W., Jr.; Harrison, E.H.; Blaner, W.S. Actions of beta-apocarotenoids in differentiating cells: Differential effects in P19 cells and 3T3-L1 adipocytes. Arch. Biochem. Biophys. 2015, 572, 2-10. [CrossRef] [PubMed]

59. Ziouzenkova, O.; Orasanu, G.; Sukhova, G.; Lau, E.; Berger, J.P.; Tang, G.; Krinsky, N.I.; Dolnikowski, G.G.; Plutzky, J. Asymmetric cleavage of beta-carotene yields a transcriptional repressor of retinoid $\mathrm{X}$ receptor and peroxisome proliferator-activated re-ceptor responses. Mol. Endocrinol. 2007, 21, 77-88. [CrossRef]

60. Shivarudrappa, A.H.; Ponesakki, G. Lutein reverses hyperglycemia-mediated blockage of Nrf2 translocation by modulating the activation of intracellular protein kinases in retinal pigment epithelial (ARPE-19) cells. J. Cell Commun. Signal. 2019, 14, 207-221. [CrossRef] 